\title{
„This borrow'd shape": \\ Barbarische Fremdheit und heroische Täuschung in Elkanah Settles The Conquest of China, by the Tartars (1676)
}

\section{Christiane Hansen}

Das heroic play, wie es für die Bühnen der englischen Restaurationszeit entwickelt wurde, stellt die Frage nach der politischen Bedeutung des Heroischen an zentraler Stelle. Als "fictions of authority “1 entwerfen die Stücke einen imaginären Raum, in dem politische und gesellschaftliche Ordnungen verhandelt werden und der so im Zentrum der kulturellen Selbstverständigung steht. Die Erosion heroischer Modelle in den 1660er und 1670er Jahren verweist dabei auf tiefer reichende gesellschaftliche und politische Probleme: Etablierte Heroisierungsmodelle waren vor dem Hintergrund politischer und konfessioneller Konflikte zu brisant oder - gerade im Nachgang des Bürgerkriegs - mit nicht konsensfähigen Figuren assoziiert, so dass die vielfach diagnostizierte Krise des Heroischen auf eben diejenigen Konflikte zurückverwies, auf deren Unterdrückung die restaurierte Monarchie aufbaute. Während so die Strategien heroischer Repräsentation von Macht zunehmend problematisch erschienen, blieb die späte Stuart-Monarchie abhängig von heroisch codierter Repräsentation und wurde vor diesem Hintergrund wahrgenommen. ${ }^{2}$ Die mittelfristig scheiternde Integrationskraft des Hofs und die zunehmende Kritik an der höfischen Kultur waren wiederum mit einer Verlusterfahrung überschrieben, die sich als zunehmende Artifizialität und Reduktion heroischen Handlungspotenzials artikulierte.

Prägend für das Genre des heroic play ist das Handlungsmuster eines ,Machttransfers': Als politische Extremsituation einer De- und Re-Konstruktion von Autorität, gerade in der projektiven Vergrößerung als ,Eroberung', interferiert das Heroische mit staatlich monopolisierter Macht. Dies überschneidet sich mit der in der Eroberungssituation angelegten Perspektive auf kulturelle Differenz, wie sie Bridget

1 So Susan Staves: Players' Scepters. Fictions of Authority in the Restoration. Lincoln und London 1979. Vgl. zum heroic play außerdem Derek Hughes: English Drama, 1660-1700. Oxford 1996. Susan J. Owen: Perspectives on Restoration Drama. Manchester 2002. Susan J. Owen: Restoration Theatre and Crisis. Oxford 1997. Nancy Klein Maguire: Regicide and Restoration. English Tragicomedy, 1660-1671. Cambridge 1992. John Douglas Canfield: Heroes and States. On the Ideology of Restoration Tragedy. Lexington 2000. Brandon Chua: Ravishment of Reason. Governance and the Heroic Idioms of the Late Stuart Stage, 1660-1690. Bucknell 2014.

2 Ausführlich dazu Kevin Sharpe: Rebranding Rule. The Restoration and Revoultion Monarchy 1660-1714. New Haven, CT und London 2013. Paula R. Backscheider: Spectacular Politics. Theatrical Power and Mass Culture in Early Modern England. Baltimore, MD und London 1993. John Spurr: England in the 1670s. This Masquerading Age. London und Malden, MA. 2000. 
Orr unter dem Schlagwort „Rehearsing Cultures“ beschrieben hat. ${ }^{3}$ Im gegebenen Zusammenhang ist entscheidend, dass sowohl die Konstruktionen kultureller Differenz als auch das Heroische selbst als Operationen zu verstehen sind, die auf Grenzziehungen beruhen und in denen Erfahrungen von Fremdheit oder Irritation angelegt sind. ${ }^{4}$ Die Konjunktur außereuropäischer, meist orientalischer Schauplätze, wie sie für die heroic plays wiederholt diagnostiziert wurde, lässt sich zwar aus der spektakulären Ästhetik des Genres ebenso offensichtlich erklären wie aus dem projektiven Potenzial und der wachsenden politischen und ökonomischen Bedeutung der außereuropäischen Welt. ${ }^{5}$ Darüber hinaus jedoch nutzen diese Texte Konstruktionen des Anderen und Fremden als Zugriffsmöglichkeiten auf das Heroisch-Exzeptionelle: Die Veräußerung heroischer Versuchsanordnungen macht die Wirkungsmechanismen heroischer Figurationen sichtbar.

Der vorliegende Aufsatz untersucht diese Konstellation am Beispiel von Elkanah Settles The Conquest of China, by the Tartars (1675/76). ${ }^{6}$ Dieser Text greift auf fast zeitgenössische Ereignisse zurück, nämlich das Ende der Ming-Dynastie 1644 mit der Eroberung Chinas durch die Mandschu. Er forciert aber den englischen Bezugshorizont: Die kontrastive Repräsentation der feindlichen Lager nähert er an die Darstellungstradition von Cavaliers und Roundheads an, den beiden opponierenden Gruppierungen in der Zeit des englischen Bürgerkriegs. ${ }^{7}$ Gleichzeitig über-

3 Bridget Orr: Empire on the English Stage 1660-1714. Cambridge 2001.

4 Verallgemeinernd lassen sich Verhandlungen des Heroischen im Rahmen einer kulturellen Arbeit an Grenzen perspektivieren, wie sie wesentlich Bernhard Giesen beschrieben hat: Bernhard Giesen: Triumph and Trauma (The Yale Cultural Sociology Series). Boulder, CO [u.a.] 2004. Bernhard Giesen: Zwischenlagen. Das Außerordentliche als Grund der sozialen Wirklichkeit. Weilerswist 2010.

5 Vgl. etwa Hughes: English Drama (Anm. 1). Canfield: Heroes and States (Anm. 1). Orr: Empire (Anm. 3). Cynthia Lowenthal: Performing Identities on the Restoration Stage. Carbondale, IL 2003.

6 Elkanah Settle: The conquest of China, by the Tartars. A tragedy acted at the Duke's Theatre. London: Printed by T[homas]. M[illourn]. for W. Cademan, at the Popes-Head in the lower-walk of the New-Exchange, in the Strand, 1676. Das Drama wird im Folgenden im fortlaufenden Text unter Angabe der Seitenzahl zitiert. Settle, der maßgeblich das Genre der horror plays prägte, gewann eine ,reputation for gratuitous stage violence, bombastic heroic speeches, and lurid stage spectacle that had no literary merit" (Jeannie Dalporto: The Succession Crisis and Elkanah Settle's The Conquest of China by the Tartars. In: Eighteenth Century: Theory and Interpretation 45: 2, 2004, 131-146, hier 131). Dieser Wertung entsprechend bleibt die Forschung zu Settle punktuell, zum hier besprochenen Stück vgl. Hughes: English Drama (Anm. 1), 98100. Orr: Empire (Anm. 3), 105-109. Jiming Yang: Performing China. Virtue, Commerce, and Orientalism in the Eighteenth Century England, 1660 -1760. Baltimore, MD 2011, 32-74. Dongshin Chang: Representing China on the Historical London Stage: From Orientalism to Intercultural Performance (Routledge Advances in Theatre and Performance Studies; 34). London 2015. - Von Sir Robert Howards Plänen zu einem stoffgleichen Stück ist nur ein Fragment erhalten; dieses entstand wohl um 1674, nachgedruckt in: Collected Works of John Wilmot, Earl of Rochester, hg. von John Hayward. London 1926, 241-247. Ein Briefwechsel indiziert, dass John Dryden eine Bearbeitung dieses Textes plante, diese ist jedoch ebenso wenig nachweisbar; vgl. Dalporto: Succession Crisis, 144.

7 Roundhead war ein zunächst abwertender Begriff für die parlamentarische Fraktion mit puritanischer Prägung. Als Cavaliers wurden umgekehrt die Royalisten um Charles I. (später 
schreibt er die genretypische Eroberungshandlung mit der einer internen Revolution, die ganz offensichtlich auf die Ereignisse in England verweist. Dies wird am deutlichsten in den Cromwellschen Zügen der Lycungus-Figur, einem General der chinesischen Armee, der die königliche Macht an sich reißen will. ${ }^{8}$ Gegen ihn wird Zungteus, der tartarische Thronfolger profiliert. Überlagert wird dieser Konflikt von einer Liebeshandlung: Zungteus liebt Amavanga, die Herrscherin einer chinesischen Provinz, die als Mann verkleidet gegen die Tartaren ins Feld zieht und ihn unerkannt zum Zweikampf herausfordert. Erst nachdem er sie vermeintlich erstochen hat, gibt sie ihm ihre wahre Identität zu erkennen.

Das Stück beginnt im tartarischen Lager mit der Exposition der Eroberungspläne und dem ersten Auftritt der verkleideten Amavanga. Der II. Akt kontrastiert damit den chinesischen Hof, wo Orunda, die einzige Tochter des alternden Herrschers, einen Ehemann und damit den chinesischen Thronfolger auswählen soll. Dies wird unterbrochen durch die Nachricht des unmittelbar bevorstehenden tartarischen Einfalls. Vor dem Hintergrund dieser politischen Bedrohung entwickelt sich im chinesischen Lager eine Intrigenhandlung: Quitazo, den Orunda als Thronfolger ausgewählt hat, liebt in Wirklichkeit Alcinda. Als Lycungus, den sie gegen den Rat ihres Vaters abgelehnt hat, dies aufdeckt, will die eifersüchtige Orunda Alcinda umbringen lassen. Orundas Intrige wendet sich jedoch gegen sie selbst, indem die von ihr engagierten chinesischen villains sie für die zu tötende Person halten und umbringen, während Lycungus Quitazo und Alcinda gefangen nehmen lässt und sich selbst zum König erklärt. Der scheiternde chinesische Herrscher überschreibt Zungteus - in deutlich dynastischer Symbolik - sein Reich mit dem eigenen Blut. Wie zuvor seine Ehefrauen nimmt er sich das Leben. ${ }^{9}$ Zungteus jedoch gelingt es, Quitazo und Alcinda zu befreien und Lycungus zu überwinden. In der letzten Szene tritt schließlich auch Amavanga wieder auf und erklärt sich bereit, als seine Frau auf weitere politische und militärische Ambitionen zu verzichten.

An diesem Stück soll im Folgenden untersucht werden, wie die Differenzkategorie des ,Barbarischen' als kulturdiagnostisch institutionalisierte, stark rhetorisierte Grenzziehung auf das heroisch Exzeptionelle appliziert wird. Auf die kaum zu unterschätzende Rolle des,Wilden' oder ,Barbarischen` im politischen Imaginären des 17. Jahrhunderts ist vielfach hingewiesen worden. Weitgehend ungeklärt ist jedoch, wie dies spezifisch mit Projektionen des Heroischen interferiert, und zwar zu ei-

auch Charles II.) bezeichnet. Beide Bezeichnungen gehen mit einer langfristig verfügbaren Stereotypisierung von Habitusmustern einher; vgl. zusammenfassend unter anderem Blair Worden: Roundhead Reputations. The English Civil Wars and the Passions of Posterity. London [u.a.] 2001.

8 Die Figur ist bei Martini vorgeprägt; vgl. Dalporto: Succession Crisis (Anm. 6), 140-141.

9 In dieser spektakulären Szene greift das Stück am deutlichsten auf das Repertoire des horror play zurück: „The Scene opens, and is discovered a Number of Murdred Women, some with Daggers in their Breasts, some thrust through with Swords, some strangled, and others Poyson'd; with several other Forms of Death" (60). 
nem Zeitpunkt, zu dem verschiedene kulturelle Verschiebungen und Konflikte am Heroischen zur Kristallisation kommen. Deshalb soll deshalb zuerst skizziert werden, welche Bedeutung dem ,barbarischen' Diskurs in Verhandlungen des Heroischen zukommt. In einem zweiten Schritt wird die Semantik einer ,tartarischen' Differenz in Settles Drama untersucht, um zu prüfen, wie diese an die Aporien des Heroischen in der Restaurationszeit gekoppelt wird. Anschließend widmet sich ein dritter Teil der Darstellung einer politischen Kultur im chinesischen Reich, die sich - wie zu zeigen sein wird - vor allem durch Täuschung und Ästhetisierung auszeichnet. Schließlich wird anhand der Begegnungen der beiden zentralen Figuren, Zungteus und Amavanga, die heroisch-admirative Wirkungsmechanik analysiert, die sich als Erfahrung des Fremden gestaltet. Auf dieser Grundlage wird erkennbar, wie Settles Drama das Heroische vereinnahmt und harmonisiert.

\section{Heroisches im imaginären Jenseits von Kultur}

Projektionen eines vorpolitischen ,Naturzustands' gewinnen in der zweiten Hälfte des 17. Jahrhunderts eine außerordentliche Bedeutung. Die Konjunktur dieser Denkfigur ist, so konstatiert Berensmeyer, ,selbst für eine so polemische Epoche radikalen gesellschaftlichen Wandels erstaunlich": ${ }^{10}$ Als Spekulation über das Jenseits kultureller Ordnung liefert der ,Naturzustand“ ein Passepartout, dessen sich in der englischen Restaurationszeit sämtliche politischen Gruppierungen in unterschiedlichen Zusammenhängen bedienen. Die Produktivität des ,Barbarischen' in Verhandlungen des Heroischen ergibt sich vor allem aus der bezeichnend uneindeutigen Stellung des Heroischen in Entwürfen von ,Kultur'. So dient das Heroische auf der einen Seite der Verständigung um die Normen und Werte, die als ,Kultur' verstanden werden, und führt in symbolischer Verkörperung dieser Normen Kultur überhaupt erst herbei: das ,Wilde' oder ,Barbarische' wird zum agonal und normativ Anderen, in dessen Überwindung das Heroische sich manifestiert. Zugleich verweist das Heroische als Phänomen residualer Fremdheit auf das Überwundene zurück, auf einen anthropologisch also ,roheren' Zustand, der sich - angeblich - durch höhere Authentizität und durch individuelle agency jenseits von rechtlich kodifizierten Ordnungen auszeichnet. Vor allem jedoch lässt sich in einer solchen rückwärtsprojizierenden Ausgrenzung eines ,barbarischen' Fremden das eigene System politischer Legitimation validieren. Konstruktionen des ,Barbarischen sind so ganz spezifisch mit der Erfahrung des Bürgerkriegs verschränkt. Gegen diesen ,barbarischen', gesetzlosen Hintergrund profiliert etwa Drydens panegyrisches Gedicht Astraea Redux (1660) die Restauration der Stuart-Monarchie als vergilische Wiederkehr eines Goldenen Zeitalters:

10 Ingo Berensmeyer: „Angles of Contingency“. Literarische Kultur im England des siebzebnten Jahrbunderts (Anglia; 39). Tübingen 2007, 182. Christopher F. Loar: Political Magic. British Fictions of Savagery and Sovereignty, 1650-1750. New York 2014. Staves: Sceptres (Anm. 1), 253-314. 
The rabble now such freedom did enjoy,

As winds at sea, that use it to destroy: [...]

They own'd a lawless, savage libertie;

Like that our painted ancestors so priz'd,

Ere empire's arts their breasts had civiliz'd. ${ }^{11}$

Analog zur römischen Eroberung Britanniens legitimiert sich folglich nicht nur der restaurierte Herrscher, sondern, abstrahierend, staatliche Ordnung überhaupt - „empire's arts“ - als kulturstiftende Kraft. Dementsprechend wird in der Restaurationszeit der Vorwurf des ,Barbarischen' gegen alles verwendet, was den Grundlagen der eigenen politischen Ordnung entgegengesetzt scheint. ${ }^{12}$ In der rhetorischen Verflachung politischer und anthropologischer Naturrechtsdiskurse dient das ,Barbarische' somit weniger der allgemeinen kulturellen Differenzierung denn einer normativen Ausgrenzung.

Figurationen des ,Barbarischen' finden sich im Restaurationsdrama zunächst nur vereinzelt. Prominent ist der Selbstentwurf von John Drydens Almanzor im Conquest of Granada (1672), der sich als noble savage außerhalb politischer und religiöser Bindungen positioniert. ${ }^{13}$ Bezeichnenderweise bleibt er jedoch nicht nur eine Einzelfigur, sondern wird schließlich in das christlich-spanische Reich integriert. Auch die vorrömische Vergangenheit Großbritanniens, die auf der elisabethanischen Bühne mehrfach aufgeführt wurde, gewinnt als dramatischer Stoff erst in den 1690er Jahren wieder Konjunktur, und zwar in dezidierter Abgrenzung zu den orientalischen Stoffen der beroic plays. ${ }^{14}$ Im Falle der Eroberung Chinas ist jedoch entscheidend, dass die Tartaren nicht - wie etwa die vorrömischen Briten die historisch überwundene, sondern die erobernde Kultur stellen. Diese Konstellation steht im Zentrum der europäischen Abhandlungen über die Tartaren. Martino Martinis De Bello Tartarico (Erstdruck 1654) wurde nicht nur - noch im gleichen Jahr - ins Englische, sondern auch ins Deutsche, Niederländische, Französi-

11 John Dryden: Astræa redux. In: The Works of John Dryden, Bd. 1, hg. von Edward Niles Hooker [et al.]. Berkeley, CA 1956, 22-31, hier 23. Vgl. zur Rhetorik der Astraea ausführlich Berensmeyer: „Angles of Contingency“ (Anm. 10), 226-232. Ingo Berensmeyer: The Art of Oblivion: Politics of Remembering and Forgetting in Restoration England. In: European Journal of English Studies 10: 1, 2006, 81-96.

12 Vgl. dazu Jennifer Richards: Introduction. In Jennifer Richards (Hg.): Early Modern Civil Discourses. Basingstoke 2003, 1-18.

13 Almanzor erklärt, er sei „as free as Nature first made man | 'Ere the base Laws of Servitude began | When wild in woods the noble Savage ran" (John Dryden: The Conquest of Granada. The Works of John Dryden, Bd. 11, hg. von John Loftis [et al.], Berkeley, CA 1978, Teil I, I.i 207-209).

14 Vgl. insbesondere das Drama von George Powell (Bonduca, or, The British heroine a tragedy, acted at the Theatre Royal by His Majesty's servants, with a new entertainment of musick, vocal and instrumental. London: Printed for Richard Bentley, 1696), eine Bearbeitung von Fletchers Bonduca, sowie Charles Hopkins' Boadicea (1697). Ausführlich dazu Jodi Mikalachki: The Legacy of Boadicea. Gender and Nation in Early Modern England (English Literatur: Renaissance Studies). London und New York 1998, 115-149. Wendy C. Nielsen: Boadicea Onstage before 1800, a Theatrical and Colonial History. In: Studies in English Literature, 15001900 49: 3, 2009, 595-614. 
sche, Spanische und Portugiesische übersetzt, Juan de Palafox y Mendozas Darstellung erschien 1671 in London als The History of the Conquest of China by the Tartars, einflussreich war außerdem der Atlas Chinensis (in englischer Übersetzung: London 1671), der ebenfalls einen Schwerpunkt auf die tartarische Eroberung legt. ${ }^{15}$ Deutlich prominenter waren chinesische Stoffe in den Niederlanden, wo die kulturellen Kontakte und auch die kolonialen Interessen stärker ausgeprägt waren, sowie im Theater der europäischen Jesuiten, deren missionarische Interessen in China sich im ausgehenden 17. Jahrhundert verstärkten. ${ }^{16}$ Die sehr unterschiedlich kontextualisierten Quellen betonen jedoch alle den Kontrast der beiden beteiligten Kulturen und die exemplarische politische Bedeutung der Eroberungshandlung: In der Konfrontation der Tartaren mit der chinesischen Hochkultur konstituiert sich das prototypische ,Barbarische nicht als eine alternative Ausprägung menschlicher Kultur, sondern als Gegensatz zu Kultur, der nur im Verhältnis zum angeblich Überlegenen überhaupt fassbar wird. Gleichzeitig wird die Kategorie des ,Barbarischen' genutzt, um dem Un-Vertrauten, in den Parametern von Kultur womöglich gar nicht zu Beschreibenden, Evidenz zu verleihen. Sie ruft zudem eine bis in die Antike zurückreichende Tradition der Indienstnahme des ,Barbarischen' zur kulturellen Selbstdiagnose auf, die in der Frühen Neuzeit etwa von Machiavelli oder Montaigne fortgesetzt wird. ${ }^{17}$ In der englischen Restaurationszeit gewinnt diese jedoch eine spezifische Färbung.

Während die Tartaren schon im europäischen Spätmittelalter zum Inbegriff des ,Barbarischen' avancierten, bleiben ihre Beschreibungen in Reiseberichten und

15 Martino Martini: Bellum Tartaricum, or The conquest of the great and most renowned empire of China, by the invasion of the Tartars who in these last seven years, have wholy subdued that vast empire. Together with a map of the provinces, and chief cities of the countries, for the better understanding of the story. London: Printed for John Crook [...], 1654. Arnoldus Montanus [et al.]: Atlas Chinensis being a second part of $A$ relation of remarkable passages in two embassies from the EastIndia Company of the United Provinces to the vice-roy Singlamong and General Taising Lipovi and to Konchi, Emperor of China and East-Tartary. London: Printed by Tho. Johnson for the author. London, 1671. Vgl. zum Hintergrund Jürgen Osterhammel: Die Entzauberung Asiens. Europa und die asiatischen Reiche im 18. Jabrhundert. München 1998. Walter Demel: China im 17. Jahrhundert: Kriegsgebiet oder Friedensreich? In: Ronald G. Asch [et al.] (Hg.): Frieden und Krieg in der Frühen Neuzeit: Die europäische Staatenordnung und die außereuropäische Welt. München 2001, 543-560. Yang: Performing China (Anm. 6), 56-59. Robert Markley: The Far East and the English Imagination, 1600-1730. Cambridge 2006, 104-142.

16 Vgl. zum historischen Zusammenhang Dalporto: Succession Crisis (Anm. 6). Charles E. Ronan und Bonnie B. C. Oh (Hg.): East Meets West: The Jesuits in China, 1582-1773. Chicago 1988. Raymond Dawson: The Chinese Chameleon: An Analysis of European Conceptions of Chinese Civilization. London 1967.

17 Vgl. Loar: Political Magic (Anm. 10). Hinrich Fink-Eitel: Die Philosophie und die Wilden. Über die Bedeutung des Fremden für die europäische Geistesgeschichte. Hamburg 1994. Monika Fludernik: Der ,Edle Wilde' als Kehrseite des Kulturprogressivismus. In: Monika Fludernik [et al.] (Hg.): Der Alteritätsdiskurs des Edlen Wilden. Exotismus, Anthropologie und Zivilisationskritik am Beispiel eines europäischen Topos (Identitäten und Alteritäten; 10). Würzburg 2002, 157-176. Christian Moser und Daniel Wendt: Das Barbarische - ein Grenzbegriff der Kultur. Einleitung. In: Carla Dauven-van Knippenberg [et al.] (Hg.): Texturen des Barbarischen. Exemplarische Studien zu einem Grenzbegriff der Kultur. Heidelberg 2014, 7-27. 
Abhandlungen des 17. Jahrhunderts begrifflich unscharf. Die Tartaren werden erst in der Konfrontation, und vor allem aus der Differenz heraus evident: Wiederkehrende Aspekte sind eine unklar abgegrenzte Ausdehnung des Machtraums, das Fehlen einer konsequenten staatlichen Organisation und das Fehlen einer Stadtkultur. Ihre Typisierung bedient erwartbare Muster, die an antike Konstruktionen des ,barbarischen' Anderen anknüpfen, vor dem Hintergrund der kulturellen Selbstdiagnosen der Restaurationszeit jedoch neue Relevanz gewinnen. ${ }^{18}$ Prägend sei dabei die unverfälschte Einwirkung der Natur. So schreibt William Temple in seiner Abhandlung Of Heroic Virtue (1690) über die Tartaren: „The Tartars, by the hardness and poverty of their country and their lives, are the boldest and fiercest people in the world, and the most enterprising “. ${ }^{19}$ Stereotyp ist ebenfalls die Darstellung als ,unverdorben' aufrichtig, also agierend jenseits von Täuschung und Illusion. Juan de Palafox y Mendoza etwa hält fest, die Tartaren seien „endued with many excellent Qualities, and shew themselves to be very noble and generous in all their Actions. They are very frank and open, and observe the performance of their word and promise very punctually in time of Peace, when they are out of fear of an Enemy".20

Die Darstellung des chinesischen Reichs ist scharf kontrastiv angelegt. Im Gegensatz zu anderen orientalischen Kulturen galt China im frühneuzeitlichen Europa nicht als Reich tyrannischer Willkürherrscher, sondern wurde mit herausragen-

18 Zentral sind Grausamkeit und Furchtlosigkeit im Kampf, so etwa Richard Blome: A geographical description of the four parts of the world, taken from the notes \& workes of the famous Monsieur Sanson, geographer to the French King, and other eminent travellers and authors to which are added the commodities, coyns, weights, and measures of the chief places of traffick in the world, compared with those of England, (or London) as to the trade thereof: also, a treatise of travel, and another of traffick, wherein, the matter of trade is briefly handled: the whole illustrated with variety of useful and delightful mapps and figures. Gent 1670, 88-89: „they are very rude, barbarous, and revengeful, not sparing their enemies, who in revenge, they eate, first letting out their Blood, which they keep using it as Wine at their Feasts". Vorsichtiger formuliert Juan de Palafox y Mendoza: „The greatest Vice of the Tartars is, their Cruelty in War, where they are very sanguinary. And it is reported, that they have been transported to that excess, as to eat the Flesh of their Enemies, which is a most barbarous Inhumanity; but of this, there is no certain proof, neither doth it appear, that the whole Nation is guilty of that Vice; perhaps this was only the rage of some few of the most barbarous, and the very Dregs of the people." (Juan de Palafox y Mendoza: The history of the conquest of China by the Tartars: together with an account of several remarkable things concerning the religion, manners, and customes of both nations, but especially the latter/ first writ in Spanish by Senõr Palafox y Mendoza and now rendred English. London 1671, 449)

19 William Temple: Miscellanea, the second part in four essays: I. Upon ancient and modern learning; II. Upon the gardens of Epicurus; III. Upon heroick vertue; IV. Upon poetry. The 2nd ed. London: Printed by J. R. for Ri. and Ra. Simpson, 1690, 194.

20 Palafox y Mendoza: The history (Anm. 18), 447. Die Semantik der Aufrichtigkeit wird im Restaurationskontext besonders brisant: zum einen vor dem Hintergrund einer Selbstwahrnehmung als theatrale Kultur, zum anderen im Verweis auf den politischen Diskurs des Puritanismus; vgl. Berensmeyer: "Angles of Contingency“ (Anm. 10), 234. Steven N. Zwicker: England, Israel, and the Triumph of Roman Virtue. In: Richard H. Popkin (Hg.): Millenarianism and Messianism in English Literature and Thought 1650-1800. Leiden [u.a.] 1988, 37-64. 
der historischer Kontinuität und Stabilität in Verbindung gebracht. Ein außerordentlicher Grad an Zivilisiertheit manifestiert sich vor allem in Zuschreibungen zeitloser ,Weisheit ${ }^{6}$ und in einer idealen staatlichen wie bürokratischen Organisation. Wichtig ist aber, dass China nicht mit einem kriegerisch fundierten Moralkodex assoziiert wurde und - damit verbunden - auch keine heroische Signatur trug. So arbeitet etwa William Temple heraus, dass die friedliche Prosperität und die fehlende agonale Energie, auch im Sinne einer Effeminisierung, das Reich angreifbar machen: „the excellence of the Chinese wit and government renders them, by great ease, plenty, and luxury, in time effeminate, and thereby exposes them to frequent attempts and invasions of their savage neighbours". ${ }^{21}$ In der Konfrontation Chinas mit den Tartaren liegt also eine Entkopplung von heroischem Habitus und politischer Größe vor, die in Settles Drama als Experimentierfeld genutzt wird, um Wesen und Geltungsansprüche heroischer Figurationen zu verhandeln.

\section{Tartarische Differenz in heroischer Perspektive}

Die heroische Semantik, die in Settles Conquest of China aus der Darstellung der tartarischen Eroberer entwickelt wird, zielt wesentlich auf ein Phantasma menschlicher agency, das sich in Gewalt, Affekt und Körperlichkeit sowie in der Vorstellung radikalen Wandels manifestiert: Die politische Ordnung des chinesischen Reichs konstituiert sich so vor dem Hintergrund einer ,barbarischen' Differenz. Die Eingangsszene stellt die Überschneidung eines furor heroicus mit einem furor barbaricus im Sinne eines seit dem Mittelalter tradierten Schreckbilds in den Mittelpunkt. ${ }^{22}$ Die Rhetorik der Tartaren kreist um stark affektiv besetzte Schlüsselbegriffe wie vengeance, rage, glory oder triumph. Rekapitulationen vergangener Siege überschneiden sich mit ebenso plastischen Antizipationen ihres Siegs über das chinesische Reich: „Imperial Heads in Blood, and Thrones in Dust, [...] The falls of Kings, and Martyr'd City's flames" (2). Ein solcher furor manifestiert sich auch in der Metaphorisierung: Feuer wird als Leitmetapher dem eisigen Klima ihrer Herkunft entgegengesetzt und exponiert ein Volk, das der agonalen Macht seines Lebensraums überlassen wird. ${ }^{23}$ Dabei bezieht Blut als zweite Leitmetapher die Ebene der Körperlichkeit ein: Ein Mangel an ,Zivilisiertheit' wird folglich mit einer naturhaft-ursprünglichen, noch nicht von Kultur vermittelten Vitalität assoziiert. Der auf agency angelegten heroischen Semantik entspricht außerdem die un-

21 Temple: Miscellanea (Anm. 19), 194. Vgl. dazu Yang: Performing China (Anm. 6), 34-38. Wit, ein Schlüsselbegriff der höfisch-literarischen Kultur im späten 17. Jahrhundert, wurde auch von Davenant in den Zusammenhang von ,Zivilisation“ gestellt; vgl. dazu Loar: Political Magic (Anm. 10), 53.

22 Ein heroischer furor wird wichtig besonders im Hinblick auf Gewalt und Affekt; vgl. Helmut Birkhan: Furor Heroicus. In: Alfred Ebenbauer (Hg.): Das Nibelungenlied und die Europäische Heldendichtung. Wien 2006, 9-39.

23 Appellativ gewendet schon in Zungteus' einleitender Rede: „The Gods that froze your Climate, warm'd your Blood“ (1). 
terliegende Zeitstruktur. In der Semantisierung der Tartaren wird der Aspekt von swiftness, rascher Bewegung, in Selbst- und Fremdzuschreibungen wiederholt hervorgehoben und der in sich stagnierenden, vergangenheitsorientierten chinesischen Kultur gegenübergestellt. Dem korrespondiert schließlich eine explizite Abkehr von diskursiven, reflexiven Problemlösungen auf der tartarischen Seite. ${ }^{24}$ Die für die chinesischen Akteure zentralen Dimensionen von Recht und Gesetz fehlen, stattdessen werden custom, honour oder manliness als Referenzwerte herangezogen, die noch nicht in eine Verrechtlichung übergegangen sind.

Spezifisch für den Kontext der restaurierten Monarchie erscheinen in diesem Zusammenhang zwei Aspekte. Erstens sind die im Stück zugrundegelegte Zeitstruktur und die Vorstellung grundlegenden Wandels für die Restaurationsepoche ganz offensichtlich problematisch besetzt. Die Hoffnung auf politische Stabilität, auf der die Restauration der Monarchie gründet, geht mit einem spezifischen, normativ grundierten Ordnungsverständnis einher, das - gerade unter dem Einfluss von Hobbes - auf einer entschiedenen Abgrenzung von einer ,barbarischen“ Ordnungslosigkeit beruht. ${ }^{25}$ Das Heroische ist hier wieder ambivalent positioniert, da es einerseits normative Wertordnungen verkörpert, diese andererseits aber gerade durch deren Transgression sichtbar macht und zusätzlich mit Prozessen kultureller Dynamik assoziiert scheint. Indem die Repräsentation der kollidierenden Kulturen im vorliegenden Text jedoch sowohl die tartarische Figuration radikalen Wandels als auch die statische Größe des chinesischen Reichs problematisiert, greift Settles Drama einen Konflikt auf, den Andreas Anter als eine grundlegende Paradoxie von ,Ordnung' beschrieben hat: Ordnung gewinnt Stabilität nur durch Flexibilität, die Ordnung nur garantieren kann, ,indem sie Unordnung zuläßt, wenn nicht sogar institutionalisiert". ${ }^{26}$ Insbesondere scheinen politische Systeme darauf angewiesen, die Notwendigkeit ihrer Ordnung präsent zu halten, was regelmäßig durch Rekurse auf ihren Gründungsakt, und damit den Zustand vor der Ordnung, geschieht. ${ }^{27}$ Im Restaurationskontext einer culture of oblivion, die

24 So beendet der tartarische König die einleitende Diskussion: „Disputes should be by Priests, not Monarchs made“ (4).

25 Andreas Anter zeigt, dass das politische Denken seit Hobbes nicht nur genealogisch auf das Problem der Ordnung zurückführbar ist, sondern Ordnung als „spezifisches Ordnungswollen" auch normativ zugrunde legt (Andreas Anter: Die Macht der Ordnung. Aspekte einer Grundkategorie des Politischen. Tübingen ${ }^{2} 2007,60$ [Hervorhebung im Original]).

26 Ebd., 55. Vgl. ähnlich Giesen: Zwischenlagen (Anm. 4), 17-18.

27 Anter: Macht der Ordnung (Anm. 25), 55. Anters Überlegungen überschneiden sich hier mit den Überlegungen zu Herausbildungen normativer Ordnungen, wie sie im Rahmen des Exzellenzclusters „Normative Ordnungen“ (Frankfurt am Main) skizziert werden. Im Mittelpunkt dieser Überlegungen steht die Annahme, dass Normen nicht theoretisch isoliert existieren, sondern im Sinne einer „embedded rationality“ in Institutionen, Bildern und insbesondere in „Rechtfertigungsnarrativen“ verdichtet werden. Indem Rechtfertigungsnarrative über die bestehende Ordnung hinausweisen, bieten sie jedoch gleichzeitig Raum für Aushandlungsprozesse; vgl. Rainer Forst und Klaus Günther: Die Herausbildung normativer Ordnungen. Zur Idee eines interdisziplinären Forschungsprogramms. In: Normative Orders Working Paper Series 1, 2010, publikationen.ub.uni-frankfurt.de/opus4/frontdoor/ 
das Vergessen des Vorausgegangenen an entscheidender Stelle der politischen Ordnung implementiert, wird jedoch gerade dies unterdrückt und von Fiktionen dynastischer Kontinuität überlagert. ${ }^{28}$ Spezifisch für das heroic play erscheint der Versuch, das Heroische im Zusammenhang von normativ-stabilisierenden, Veränderungsprozesse ausblendenden Narrativen anzuwenden.

Zweitens forciert Settles Conquest of China den spezifisch englischen Bezugshorizont, indem er die kontrastive Repräsentation der feindlichen Lager, wie erwähnt, an die Darstellungstradition von Cavaliers und Roundheads annähert, damit die zunehmende Enttäuschung über die restaurierte Monarchie ins Blickfeld rückt und gleichzeitig die genretypische Eroberungshandlung mit derjenigen einer internen Revolution überschreibt, die ganz offensichtlich auf die englische Revolution verweist. Indem also eine innere Bedrohung des chinesischen Reichs die auBenpolitische Bedrohung überlagert, wird der Transfer der staatlichen Macht an die tartarischen Eroberer ausgeblendet. Zugleich legitimiert die Heroisierung der Zungteus-Figur die tartarische Herrschaft. ${ }^{29}$ Zungteus wird zwar als herausragender tartarischer Krieger eingeführt, ist aber - gerade durch die Zerrissenheit zwischen Liebe und Krieg - als prototypische, und damit vertraute Figur eines heroic play gestaltet. Ferner berichtet er, in Friedenszeiten Teile seiner Erziehung in China genossen zu haben, vielsagend in der Phase seiner Mann-Werdung: „Where Child wears out, and growing Man appears" (6). Zungteus' heroische ,Differenz' erweist sich so nicht nur in der exzeptionellen Verkörperung der tartarischen Tugenden, sondern auch in seiner Entfremdung von ihnen, die perspektivisch unterschiedlich bewertet wird: Kommt der chinesische Herrscher zu einer Höchstwertung, ${ }^{30}$ so provoziert Zungteus aus Sicht der übrigen Tartaren, maßgeblich der seines Vaters und seines Ratgebers Palexus, den Vorwurf der Effeminisierung. ${ }^{31}$ Da Männlichkeit bei den Tartaren als normativer Referenzwert gilt, wird jede Abweichung als ,weiblich' abgewertet. Zugleich - und damit zusammenhängend - überschnei-

deliver/index/docId/8125/file/ForstGuentherDie_Herausbildung_normativer_Ordnungen. _Zur_Idee_eines_interdisziplinaeren_Forschungsprogramms.pdf, 29. März 2016. Rainer Forst: Zum Begriff eines Rechtfertigungsnarrativs. In: Andreas Fahrmeir (Hg.): Rechtfertigungsnarrative. Zur Begründung normativer Ordnung durch Erzäblungen (Normative Orders; 7). Frankfurt am Main [u.a.] 2013, 11-28.

28 Vgl., vor allem zum Fiktionscharakter, Berensmeyer: „Angles of Contingency“ (Anm. 10), 215-216.

29 Diese Aufwertung der Eroberer entspricht in weiten Teilen der Darstellung bei Martini, der auf die Assimilationsleistung der Tartaren einerseits und die gewonnene Machtstabilität andererseits verweist - so auch in der Hoffnung auf neue Möglichkeiten jesuitischer Einflussnahme in China.

30 Der Verweis auf Zungteus' Exzeptionalität legitimiert dabei die eigene politische Resignation: „Zungteus has a mind so God-like, great, | And Generous, he can no Equal meet. When e'r he fights, unmatch't he has the Odds; | Who fights with him makes War against the Gods" (40).

31 So urteilt Palexus: „In this unmanly, and so mean design, | From Duty and from Honour you decline“ (8); später Theinmingus: „Such an Effeminate design will shame | Thy sleeping Ancestors untainted Fame“ (8). 
det sich das Gendering der Figur mit kultureller Zugehörigkeit und Differenz, betont also Zungteus' Annäherung an die hochgradig zivilisierte, dabei aber als unheroische, feminisierte chinesische Kultur.

Entsprechend wird im Falle von Zungteus auch das Verhältnis des Helden zum politischen Machtmonopol doppelt pointiert: Erstens wird es mit einem VaterSohn-Konflikt auf der tartarischen Seite überschrieben, zweitens in der dynastischen Vereinnahmung durch den chinesischen Herrscher wiederum harmonisierend eingebunden. Indem Zungteus jedoch als genrespezifische heroische Figur eines heroischen Dramas erkennbar wird, wird er als solche auch evident, verliert also seine potenzielle Fremdheit: Die Transgressivität der heroischen Figur, wesentlich Affekt und Gewalt, wird auf den tartarischen Hintergrund der Figur verlegt, somit im vertrauten Rahmen kultureller Differenzzuschreibungen fixiert und in ihrem Irritationspotenzial sichergestellt. Die Zuschreibung heroischer Qualitäten an eine kulturell fremde Figur dient folglich - als vereinnahmender Mechanismus - einer Harmonisierung des Heroischen.

\section{Versionen des Theatralen auf chinesischer Seite}

Während das tartarische Stereotyp auf Maskulinität, naturhafte Authentizität und kriegerische agency zielt, profiliert die Bühnenhandlung auf der chinesischen Seite den Aspekt der Täuschung. Assoziiert mit einer metadramatischen Ebene und codiert als kulturelle Opposition lenkt diese Verschränkung den Blick auf die Wirkungsmechanismen heroischer Differenz. Die theatrale Kultur am chinesischen Hof wird im II. Akt exponiert mit dem Maskentanz der zwölf möglichen Thronfolger, die sich dem König und der Prinzessin präsentieren: „Enter twelve Princes in Masquerade, mask'd, Quitazo and Licungus being of them, a Maskal Dance is performed; which ended, the Princes unmask, and the King and Princes rise" (10). Dramaturgisch zielt diese Szene in denjenigen Bereich von Künstlichkeit und Verstellung, die dem zuvor exponierten tartarischen Lager fremd ist: Gerade die für die Tartaren hervorgehobenen Dimensionen von Natur, Körperlichkeit, agency und rascher vorwärtsgerichteter Bewegung werden im Maskentanz distanzierend und ästhetisierend unterdrückt. Die zwölf Prinzen erweisen sich zudem als Spektrum von Entwürfen des Maskulinen - ganz deutlich im Kontrast zu den intern wenig differenzierten, ausgesprochen männlichen Tartaren. Zudem wird die chinesische Kultur nachdrücklich als eine visuelle gekennzeichnet: „let your Eyes | Mark out that worth" (10), weist der König seine Tochter an, und auch diese leitet ihre Überlegungen mehrfach vom Sehsinn ab. ${ }^{32}$ Das ,Barbarische‘ steht also einer hochgradig visuellen Inszenierung von Kultur entgegen, die nicht auf einen ästhetischen Be-

32 Zuerst formuliert sie noch skeptisch („My Eyes my greatness wrong“ [10]) und wirft auch ihrem Vater vor, sich vom Sehsinn täuschen zu lassen („How can your wandring fancy stray so far | That your weak Eyes their merit can compare" [11]). Sie bleibt aber selbst durchgängig auf der visuellen Ebene. 
reich beschränkt ist, sondern ganz unmittelbar politische Entscheidungen herbeiführt.

In diesem Zusammenhang ist auch die Wahl der Tochter überaus bezeichnend. Der König beschreibt Quitazo in der Semantik eines Melancholikers („gloomy Face“, „angry and disdainful frown“, „Sullenness that scorns a Crown“ [10]), was durch die Tochter jedoch umgedeutet wird: „something seems Imperial in his brow“ (10); „His Gallantry is in that Look exprest“ (11); ,see what charms his softer looks impart" (11); „A Modesty in this dark brow I find; | The noblest mark of an Illustrious mind“ (11). Die Wertvorstellungen, die an eine Herrscherfigur geknüpft werden - imperiality, gallantry, nobility -, werden ebenfalls als visuelle Codes artikuliert. Indem Orunda als Frau, in der passiv distanzierten Rolle eines Publikums vor einer Bühne, über die politische Zukunft Chinas entscheiden muss, forciert die Szene nicht nur die Frage nach der Legitimation politischer Autorität, sondern perspektiviert sie im Rahmen frühneuzeitlicher Überlegungen zu Wahrnehmung und Illusion. ${ }^{33}$

Diese Exposition politischer Entscheidungen auf ästhetischer Grundlage zielt offensichtlich in den Bereich der spektakulären Repräsentation und Inszenierung königlicher Macht. Settle ergänzt dies mit Beispielen von Verstellung und Täuschung, die nicht primär dem ästhetischen Geltungsbereich zugeordnet sind. Diese sind in der metatheatralen Tektonik wiederum miteinander assoziiert: Orunda nutzt die Verkleidung, um sich in ihrer Rolle als eifersüchtige Liebende der politischen Verantwortung zu entziehen, Quitazo und Alcinda nutzen Schäferkostüme für ihr heimliches Treffen - ein Verweis auf die Tradition der pastoralen Dichtung. ${ }^{34}$ Bezeichnenderweise wendet sich Orundas Intrige dann jedoch gegen sie selbst, da ihre eigene Identität durch die Verkleidung ebenso unkenntlich wird wie die ihres Opfers: So verteidigt sich der Mörder gegen den Vorwurf, die falsche Frau umgebracht zu haben, mit dem Hinweis „'Tis a Woman in disguise, | And 'tis by that Description that she Dies“ (48). Indem ausgerechnet die Verkleidung zum bestimmenden Merkmal wird, führt die Szene die Möglichkeiten zuverlässiger Identifizierung ad absurdum.

Die Intrige des Lycungus beruht ebenfalls auf Täuschung, dient aber umgekehrt der Anmaßung politischer Macht. Indem Lycungus seine individuelle agency einer göttlich legitimierten, statischen Macht entgegensetzt, formuliert er sein Vorhaben als Herausforderung der Götter, die er in die Rolle eines passiv bewundernden Publikums verweist:

33 Den epistemologischen Hintergrund diskutiert ausführlich Berensmeyer: „Angles of Contingency"(Anm. 10), 133-140.

34 So Quitazo: „For thus in borrow'd Shapes the Gods of old | In Masquerade did their Love-Parleys hold“ (45). Vgl. zum Bezugshorizont der pastoralen Dichtung Pilar CuderDominguez: Reconceiving Gender Alterity. Political Commentary in Woman-Authored Plays (1669-1713). In: Rüdiger Ahrens (Hg): The Construction of the Other in Early Modern Britain: Attraction, Rejection, Symbiosis (Anglistische Forschungen; 433). Heidelberg 2013, 73-84, hier 80-81. 
Ye Gods of China, if you are such tame

And inoffensive things, as our Priests frame,

Whose Pious Eares and Eyes and tender Sense

Delights in nought but Good and Innocence:

Draw back your Sun, and vele [sic.] your selves in night:

I shall Act Deeds, which all weak Eyes will fright.

But if the Nature of your God-Heads be

Couragious, savage, feirce and bold like me.

Heav'n wear no Clouds, and Gods take a full view:

Look and Admire at what my Hand dares do. (33-34) ${ }^{35}$

Durch die erneute Fokussierung auf die visuelle Wahrnehmung einerseits, das mittelbar weibliche Gendering der so apostrophierten Götter andererseits ${ }^{36}$ rekurriert Lycungus auf die vorausgehende Maskentanzszene. Er profiliert außerdem seinen heroischen Selbstentwurf gegen eine göttliche Allwissenheit, die sich mit einem passiven Publikumsstatus überschneidet. Sein daraus abgeleiteter Revolutionsversuch gründet auf der Abhängigkeit politischer Autorität von militärischer Macht: Gehorsam, so argumentiert er, beruhe auf (Ehr-)Furcht. Solche könne jedoch nicht königliche Größe, sondern nur militärische Gewalt hervorrufen. ${ }^{37}$ Konsequent löst er sich somit selbst aus der Rechtsverbindlichkeit souveräner Herrschaft. Im offensichtlichen Rekurs auf die Erfahrung des englischen Bürgerkriegs reflektiert die Passage so den Missbrauch heroischer Muster zur Anmaßung von Macht. Diese Haltung wird jedoch gerade nicht dem ,barbarisch'-tartarischen Lager zugerechnet, sondern dem chinesischen Reich. Politische Ordnung wird damit als ein Zustand gefasst, der durch (pseudo-)heroische Selbstentwürfe ständig gefährdet bleibt.

Die chinesischen Auftragsmörder (villains) schließlich, die Orunda engagiert, werden immer wieder mithilfe eines ,barbarischen 'Vokabulars beschrieben: Sie erscheinen als „Rude Savage Villains“ (47), animalisiert als „Barb'rous Dogg“ (52) von einer „bruitish ignorance“ (48). Entscheidend aber wird das semantische Spektrum von furor, Körperlichkeit und Affekt im Falle dieser Figuren nicht herangezogen: Ihre monströse Grausamkeit ist nicht ihr eigentliches Wesen, sondern wie die Fähigkeit zur Verstellung - skrupelloses Kalkül. ${ }^{38}$ Im Gegensatz zur Auf-

35 Der gestürzte König fordert komplementär dazu die Götter auf, angesichts solcher Verbrechen der Erde das Licht zu versagen: "Spangled with Bloody Comets may the Ayr | All hung with Black, the Garb of Horror wear, | Your Heav'n, and you more Night, more Darkness need | To be the fit Spectatours of this Deed" (57).

36 So sind Attribute der Götter („tender“, „innocence“, „weak“, „fright") mit Weiblichkeit assoziiert, während Lycungus' Selbstentwurf („Couragious, savage, feirce and bold“) auf Maskulinität abhebt.

37 Lycungus überkreuzt dabei politische, sakrale und wirkungsästhetische Ebenen: „But though we Souldiers through the World strike Awe; | We make Obedience, but Kings give it Law. | And all the Trophies of a Conquering Sword | Do but build Temples, where their Name's ador'd. | Men dread the Voice of Thunder, but admire | And Reverence the Gods that lend it fire" (54).

38 So konstatiert der $1^{\text {st }}$ Villain auf Orundas Versuch, ihre königliche Autorität geltend zu machen: „Madam, we own no Soveraign but Gold“ (47). 
richtigkeit der Tartaren repräsentieren sie eine diabolische Kehrseite von Kultur, die Konzepte heroischen Handelns in eine an Auftrag und Gewinn ausgerichtete Verhaltenslogik überführt: „Though murd'ring I have my profession made; | No Artist but may fail once in his Trade" (48).

\section{Heroische Täuschung als Erfahrung des Fremden}

Es ist jedoch die Amavanga-Figur, die den thematischen Komplex der Verstellung am deutlichsten auf das Heroische hin fokussiert. Amavanga, verkleidet als Mann in Rüstung, ruft als weibliche Stellvertreterin eines männlich imprägnierten $\mathrm{He}-$ roismus das den Chinesen scheinbar fehlende ,Männliche' umso deutlicher auf. Jedoch ist ihr der amazonische Habitus gerade nicht selbstverständlich verfügbar, sondern sie äußert schon in der Eingangsphase massive Zweifel am Erfolg der eigenen Verstellung und an ihrem dafür notwendigen Mut: Ihre weibliche Identität scheint ständig durch die angenommene maskuline Rolle hindurch und stellt diese als Verkleidung aus. Eine solche Künstlichkeit haftet etwa den britisch-amazonischen Dramenfiguren nicht an: Dort steht im Gegenteil verstörende Brutalität im Vordergrund, die über das weibliche Gendering ausgegrenzt wird. Ein solches amazonisches Angstbild bedient Settles Amavanga gerade nicht: Während bei Zungteus ein primär ,heroischer ${ }^{6} \mathrm{Zug}$ (codiert etwa als courage, fierceness, resolution) in seiner ,tartarischen Natur' zu liegen scheint, ist Amazonisch-Heroisches bei Amavanga immer bereits Verstellung gegen ihre ,Natur'. Dies perspektiviert Settle sowohl als Verstellungsleistung als auch als Effekt. Die Überlegungen zu Verstellung und Täuschung werden so mit einer wirkungspoetischen Reflexion auf die heroische Konstruktion verbunden. Das Gendering der Figur dient weniger einer Stellungnahme im Geschlechterdiskurs, als dass es die implizite Theatralität des heroischen Habitus bloßlegt: Auf derjenigen kulturellen Entwicklungsstufe, die dem chinesischen Reich zugeschrieben wird, ist das Heroische nur noch im theatralen Modus verfügbar. ${ }^{39}$

In der Anfangsphase der Handlung sucht Amavanga die eigene Verstellung noch als Wagnis heroischer Größe zu kennzeichnen und als solches zu legitimieren. Die Dimensionen, gegen die die Täuschung profiliert wird („World“, „Empire“) verstärken den Eindruck einer agonalen Leistung. Die Bildlichkeit assoziiert ihr Unternehmen jedoch zugleich mit Lycungus' Ambitionen:

39 Diese metadramatische Qualität wird durch die theatergeschichtliche Perspektive des Epilogs betont: Dort lässt Settle Mary Lee, die Darstellerin der Amavanga, reflektieren, dass im elisabethanischen Theater die Frauenfiguren von Männern gespielt wurden - auf der Restaurationsbühne, wo erstmals Schauspielerinnen auftraten, diese also konsequenterweise auch männliche Rollen übernehmen sollten. Entscheidend verortet Settle auch hier die Amavanga-Figur in einem ästhetischen Geltungsraum und hebt den Grenzbereich zwischen Rolle und verkleideter Identität hervor. Vgl. zur Anverwandlung des Amazonenmotivs ausführlich Yang: Performing China (Anm. 6), 32-74. 
Amavanga in this borrow'd shape,

Will th'Eye of a deluded World escape:

All danger of discovery I defie.

Ile look, and speak, and act a part so high,

Shall cheat an Empire. (4)

Aus der Perspektive der erfolgreich getäuschten Tartaren gewinnt Amavanga gerade aus dieser Verstellung heraus jedoch heroische Züge, die als Erfahrung von Fremdheit gefasst werden: Der intransparente Grenzbereich von Identität und Rolle generiert eine spezifisch heroische Inkommensurabilität. Zwei Passagen aus dem Stück zeigen dies besonders deutlich. In der ersten trifft Zungteus erstmals mit der verkleideten Amavanga zusammen, die von ihrer ebenfalls verkleideten Vertrauten Vangona begleitet ist. Er zeigt sich nicht nur beeindruckt von der heroischen Größe des Gegners, sondern artikuliert auch die eigene Schwäche gegenüber der Figur und deren paralysierende Wirkung, die er sich nicht erklären kann. Ausweichend bedient er ein semantisches Spektrum des Magischen und - unklar davon abgegrenzt - des Sakralen. Während die unterliegende Erotisierung der Szene an dieser Stelle nur dem Publikum evident wird, fokussiert Zungteus' Reaktion die Nähe von Bewunderung und Staunen zu Verunsicherung und Furcht:

$\mathrm{Ha}$ ! There's Enchantment there, and something stole

Through that soft Circle, has surpriz'd my Soul.

I cannot fear, and yet me thinks I quake

Dar'd by that breath, my trembling Spirits shake.

Great God's! what sudden Chill has seiz'd my blood;

Something - no matter what; be't ill, or good,

I blush for't, and 'tis gone. (4-5)

Wichtig ist, dass die so umrissene Reaktion gerade diejenige Ebene der Körperlichkeit betrifft, die bei den Tartaren mit dem unverfälschten heroischen Habitus verschränkt wurde. Erneut wird die visuelle Wahrnehmung betont („Something I feel so Sacred at thy sight" [5]). Als überwirklichen Einfluss betont Zungteus die irritierende körperliche Präsenz der in ihrer Wirkung nicht greifbaren Figur („Some Divine pow'r has humane likeness worne“ [5]) und nähert diese sakral konnotierte Macht gleichzeitig dem Schrecken an („If supernatural pow'r this terrour draws“ [5]). Im cartesianischen Verständnis des Admirativen ist dabei die ethische Qualität (,ill, or good“) des Auslösers nicht zu entscheiden. Vangonas Mahnungen, der offensichtlich irritierte Zungteus könne die Verkleidung durchschauen (,a searching wonder in the Princes Eye“ [4]), spiegeln schließlich eine erkenntnistheoretische Dimension des Staunens, wie sie die neuplatonische und christliche Erkenntnislehre prägt. ${ }^{40}$ Indem Settle die Szene poetologisch auf die admirative

40 Berührt ist damit erstens der Überschneidungsbereich von staunender Bewunderung und Schrecken beziehungsweise Furcht, außerdem zweitens das ambivalente Verhältnis des Staunens zur Erkenntnis (so versteht die christlich-mittelalterliche Philosophie stupor, die Steigerungsform der admiratio, als Vernunft-Starre), und schließlich drittens die von Descartes geprägte Auffassung des Staunens als primär ästhetische Emotion; vgl. Nicola Gess: 
Ästhetik des heroic play hin perspektiviert und deren Künstlichkeit herausarbeitet, geht er so über die dramatische Ironie der Begegnung deutlich hinaus.

Zweitens, und verschärfend, konfrontiert die Eingangsszene des III. Akts diese Überwältigung mit der Ebene der Gewalt. Im Rückblick auf das unmittelbar vorausgehende, aber szenisch ausgesparte Kampfgeschehen beschreibt Zungteus Amavanga als irritierend fremde Figur, die nicht das vertraute ,Andere' der gegnerischen chinesischen Kultur verkörpert, sondern - aus diesem herausfallend - das eigene, martialisch geprägte Ethos spiegelt, überbietet und verfremdet. Diese admirative Perspektive manifestiert sich ein weiteres Mal als ein diffuses Bewusstsein von Unwirklichkeit. So rekapituliert er, bezeichnenderweise mit falscher Pronominalisierung:

He Kills with such a gay undaunted Port;

Fighting seems not his business, but his Sport.

His Looks and Actions speak indifferent styles.

Rage frowns in other Brows, in his it smiles.

That makes him in this more than humane Task,

Seem both to act a Slaughter, and a Mask. (22)

Die plastisch geschilderte Gewalttätigkeit der Figur driftet vom Barbarisch-Animalischen in ein zumindest der Tendenz nach auratisch-heroisches Spektrum. Bis auf die Wortebene an die Maskentanzszene anknüpfend, ist die Begegnung mit dem Heroischen als ästhetische Erfahrung gestaltet. Wiederum dient das Gendering der Amavanga-Figur der Bloßlegung von Konstruktion: Aus der verdeckten Erotisierung der vermeintlich männlichen Kriegerfigur formiert sich, letztlich als Täuschung, eine heroische Aura.

Bezeichnenderweise scheitert diese Illusion, als der Text in die genretypische Zweikampfszene hineinsteuert, die mit spezifisch heroischen Erwartungen besetzt ist. In einer Engführung der zentralen Themen wird diese bei Settle auf den Aspekt der Zivilisation hin perspektiviert: So nobilitiert Amavanga den Zweikampf in Abgrenzung von einer animalisch konnotierten, anonymen Schlacht von Massen, aber auch vom Duell mit Sekundanten als "Customary Barb'rousness" - als pseudozivilisierte Tendenz eines „Decrepit Age“ (38). Ihrem grandiosen Selbstentwurf fehlt aber im Zweikampf die körperliche Entsprechung. Ihr Scheitern spiegelt im Gegenteil eben diejenige metaphorische Verzauberung ihres Gegners, wie sie zuvor etabliert wurde: „I'm charm'd even by that Courage - I am killed“ (38). Amavanga übernimmt damit die auf sie selbst angewandte Symbolsprache, wendet sie aber auf eben diejenige Figur an, die jenseits von Verstellung agiert. Die Zweikampfsequenz ist so darauf ausgelegt, die nur oberflächliche Anmaßung einer heroischen Rolle bloßzulegen.

Staunen als ästhetische Emotion. Zu einer Affektpoetik des Wunderbaren. In: Martin Baisch [et al.] (Hg.): Wie gebannt. Ästhetische Verfahren der affektiven Bindung von Aufmerksamkeit (Litterae; 191). Freiburg [u.a.] 2013, 115-132. Stefan Matuschek: Über das Staunen: eine ideengeschichtliche Analyse (Studien zur deutschen Literatur; 116). Tübingen 1991, 24-79. 
Bezeichnenderweise unterdrückt das Drama anschließend die Bedeutung der Amavanga-Handlung, indem Lycungus als Zungteus' eigentlicher Gegenspieler etabliert und letztlich überwunden wird. Das Schlusstableau der abgeschlossenen Eroberungshandlung charakterisiert die Sicherung politischer Stabilität und Kontinuität als Assimilations- und Ausgleichsbewegung. ${ }^{41}$ Dabei wird die chinesische Krone zwischen dem tartarischen Eroberer und Quitazo geteilt, der - so Zungteus' programmatische Ansage des Eroberers - seine tartarische Natur zivilisieren soll: „Your Milder Presence will auspicious be | And Civilize my Rougher Tartary“ (67). Zungteus will umgekehrt für die Verteidigung des Reichs einstehen: „I'le Teach their softer Nature Arms and War" (67). Dabei werden die verschiedenen Projektionen des Heroischen, neben Lycungus' scheiternder Machtübernahme vor allem der heroisch-amazonische Täuschungsversuch der Amavanga-Figur, als Irrtum gekennzeichnet: „I was compelled | and snar'd by glory to that fatal fight“ (67), reflektiert Amavanga, die - durch einen göttlichen Eingriff gerettet - in ihre genretypische Rolle als Braut des heroischen Protagonisten überführt wird. Amavangas weibliche Tugend erweist sich damit nicht in der heroischen Tat, sondern im Verzicht auf politische agency. Auch im Fall der männlichen Hauptfigur beendet die dynastisch legitimierte Übernahme königlicher Autorität das im engen Sinne heroische Narrativ und löst die Reibung von heroischer Figur und politischer Institution auf: Die problematische Verweisstruktur des Heroischen auf das, was - in der normativen Einfärbung des 17. Jahrhunderts - der Kultur, im Sinne von politischer Ordnung, vorausgeht, wird in eine Assimilationsfigur übersetzt. Diese harmonisierende Konstruktion erweist somit eine generelle Schwierigkeit der un-tragischen Poetik des heroic play, welche die admirative Perspektivierung meist ohne den Heldentod sichern muss. ${ }^{42}$

Elkanah Settles Conquest of China zeigt beispielhaft im Kontext der frühen 1670er Jahre, wie Konstruktionen des Heroischen nicht nur in je spezifischen Kontexten stehen, sondern wie auch die diskursiven Felder, innerhalb derer diese überhaupt relevant werden, historisch variieren. Ausgehend von Konstruktionen einer ,barbarischen' Differenz wird in Settles Conquest of China eine Semantik des Heroischen entwickelt, die deutlich auf Vitalität, Maskulinität, Ursprünglichkeit und Authentizität abhebt und die die rückwärtsverweisende Bindung des Heroischen an Fiktionen eines vorpolitischen Zustands aufzeigt. Ein anthropologischer Roh-

41 Die zeitspezifische Stoßrichtung dieser Schlussbildung betont auch Dalporto: „The Conquest of China represents a broad range of English political expectations and fears and seeks to assuage these fears by rewriting Chinese history as a way to universalize the innate endurance of the Restoration settlement." (Dalporto: Succession Crisis [Anm. 6], 134)

42 Dies als Grundproblem des Heroischen auch bei Giesen: „if the charismatic appeal to followers cannot stand the test of time, if it collapses suddenly or fades away in the routines of ordinary life [...], the hero is dethroned and sometimes turned into a perpetrator not just by outsiders but also by what was his own community before. [...] One way of preventing the routinization of charisma consists of killing the mortal hero in order to keep the sacred charisma alive" (Giesen: Triumph and Trauma [Anm. 4], 19). 
zustand als Fiktion im politischen Imaginären, auf den das Heroische verweist, steht so weniger einer heroisch vollkommenen Kultur entgegen als einer hochgradig artifiziellen Inszenierung von Kultur, der das Heroische fremd geworden ist. Als zentrales und letztlich nicht aufzulösendes Problem heroischer Konstruktionen identifiziert der Text die Überkreuzung von naturhafter Authentizität, wie sie dem tartarischen Spektrum zugeordnet ist, mit dem Problemkomplex der Täuschung, der als Problem der eigenen politischen Kultur und der admirativen Ästhetik des heroic play gekennzeichnet wird.

Geschlechtliche und kulturelle Differenz dienen dabei der Bloßlegung der am Heroischen beteiligten Prozesse: Insbesondere anhand der tartarischen Reaktion auf die verkleidete Amavanga zeigt der Text auf, wie die Wirkung des Heroischen mit seiner zwischen Ästhetik, Erotik und Sakralität angesiedelten Macht gerade in der visuellen und physischen Unmittelbarkeit ihrer Wirkung opak bleibt und sich letztlich immer als Täuschung konstituiert. Die tartarische Eroberung Chinas als experimentelle Entkopplung von heroischer agency und politischer Größe im politischen Imaginären wird bei Settle entsprechend in ein Phantasma idealer Herrschaft aufgelöst, die das eigentlich Heroische nivelliert. 